\title{
Invest As I Say, Not As I Do? Gender Differences In Financial Risk Preferences
}

\author{
Nancy Ammon Jianakoplos (E-mail:Nancy.Jianakoplos@ColoState.edu), Colorado State University
}

\begin{abstract}
This paper examines gender differences in stated versus observed financial risk preferences. The responses of women versus men to a question regarding financial risk preferences are compared to the proportion of risky assets held in their portfolios using data from the 1995 Survey of Consumer Finances. The data show that women are more likely to express an unwillingness to take financial risks. Stated financial risk preferences are found to be consistent with observed risk preferences at the ordinal, but not the quantitative, level. Contradicting their stated risk preferences, risky assets constitute, on average, one-third of the financial assets of households that indicate they are unwilling to take any financial risks. Financial planners and advisers frequently use a client's expressed willingness to take on risk as an important determinant in asset allocation recommendations. Consistent gender differences in these responses, in addition to inconsistencies between the client's stated risk preferences and observed portfolio allocation, may lead advisers to make inappropriate recommendations.
\end{abstract}

\section{Introduction}

$\mathfrak{J}$

he purpose of this paper is to investigate whether stated and observed financial risk preferences differ between men and women. This issue has important implications for financial education and counseling. One of the first questions a financial planner usually asks a client is how much risk the client is willing to accept. Based on this statement of risk preference, the planner suggests an appropriate mix of financial assets. The focus of this analysis is to determine whether reliance on stated risk preferences is warranted and whether such reliance will lead to systematic differences in asset allocations by gender.

The asset allocation decision is a critical factor determining the outcome of financial investments. The difference between selecting a conservative versus an aggressive (more risky) mix of financial assets can make a huge difference in expected returns, especially over longer time periods. For example, consider two individuals who each invest $\$ 10,000$ on January 1, 1976. One puts all of the money in small company stocks (a very aggressive and risky portfolio), while the other puts the money in a government bond fund (a very conservative and much less risky portfolio). Based on historical data from Ibbotson Associates (1996), twenty years later at the end of 1995, the portfolio of small-company stocks would be worth $\$ 128,717$ in inflation-adjusted terms, compared to only $\$ 26,348$ for the government-bond portfolio. The aggressive investor would have accumulated almost five times as much wealth as the conservative investor. This example illustrates the crucial importance of the asset allocation decision to investment returns. Since asset allocation decisions are based in large part on an investor's tolerance for risk, an assessment of the how closely stated risk preferences coincide with observed holdings of risky assets has important implications for investor wealth.

Data from the 1995 Survey of Consumer Finances (SCF95) are used to examine differences in stated versus observed risk preferences. This survey provides the information necessary to examine this issue since survey respondents were asked how much financial risk they would tolerate and also reported the dollar value of their assets

Readers with comments or questions are encouraged to contact the author via email. 
and liabilities, so that the observed financial risk in their portfolio can be determined. In the next section, the relation between portfolio allocation and risk preferences is reviewed. In the following section, the evidence regarding gender differences in financial risk preferences is reviewed. The next section describes how measures of stated and observed risk preferences are constructed from the data. The following section examines the empirical evidence. In the final section, a summary of the findings is provided and policy conclusions are drawn.

\section{Risk and Portfolio Allocation}

Financial risk refers to the volatility of financial returns. Most people are assumed to be risk averse, i.e., they dislike upward and (particularly) downward swings in the value of their investments. Many financial planners suggest different portfolios for different levels of risk tolerance. For example, TIAA-CREF (1998) suggests four alternative portfolios based on the degree of investor risk preference ranging from an allocation of 30 percent equities and 70 percent non-equities for the conservative investor to 80 percent equities and 20 percent non-equities for the aggressive investor. Likewise, Fidelity Investments (no date) suggests six different portfolio allocations depending on the investor's "objectives and tolerance for risk" ranging from 100 percent stocks for the most aggressive investor to 100 percent money market instruments for "those who cannot tolerate swings in value".

A fundamental principle of finance is that higher risk is associated with higher returns. Thus, investors who are willing to tolerate more risk are rewarded on average with higher returns. Symmetrically, safer portfolios typically provide lower returns for investors. Consequently, a correct assessment of an individual investor's risk tolerance is essential for financial planning. Thus, this investigation into how closely stated risk preferences accord with investor's risk taking behavior can provide useful information for financial planners when making asset allocation recommendations.

\section{Gender and Risk Preferences}

Several studies have looked at women and financial risk taking. Jianakoplos and Bernasek (1998) find that as their wealth increases, women hold a smaller proportion of their wealth in risky assets compared with men. Bajtelsmit, Bernasek, and Jianakoplos (1999) find that the same result holds when only risky pension assets are considered. Hinz et. al. (1990) and Bajtelsmit and VanDerhei (1996) find that women invest pension assets more conservatively than men.

The correlation between stated risk preferences and observed portfolio allocation has been assumed in some previous research and investigated in at least one other study. Sunden and Surette (1998) include investor's stated risk preferences as explanatory variables in an equation explaining allocation of defined contribution pensions into mostly stocks or mostly bonds. They do not consider whether these responses accurately reflect the household's risk preferences. They find that households indicating they are willing to take more risk are significantly more likely to invest mostly in stocks and significantly less likely to invest mostly in bonds than households unwilling to take financial risks. Schooley and Worden (1996) use one-way analysis of variance methods to examine whether stated risk preference correspond to observed portfolio allocation based on data from the 1989 Survey of Consumer Finances. They conclude that stated risk preferences are consistent with observed portfolio allocations, but they do not consider the correlation by gender. One of the innovations of this study is to consider the possibility of systematic gender differences in the correlation of stated and observed risk preferences.

\section{Data and Method}

The empirical analysis is based on data from the SCF95, sponsored by the Federal Reserve System. This survey sampled 4,299 households, chosen to provide a comprehensive picture of the financial situation of all U.S. households. Because wealth is highly skewed, the survey over-sampled high-income households. Accordingly all summary statistics reported in this paper are sample weighted to adjust for the effect of this over-sampling. In addition, this analysis makes use of the imputed values of missing data produced by researchers at the Board of Governors of the Federal Reserve System. More information concerning the SCF95 is provided by Kennickell, StarrMcCluer, and Sunden (1997). 
The measure of stated risk preference used in this analysis is the answer of the survey respondent to the following question: "Which of the statements on this (page/card) comes closest to the amount of financial risk that you (and your husband/wife) are willing to take when you save or make investments? 1/ take substantial financial risk expecting substantial returns, 2/ take above average financial risk expecting to earn above average returns, 3/ take average financial risk expecting to earn average returns, or 4/ not willing to take any financial risks." One individual from each household surveyed answered this question. For single households, the respondent was the head of household, while for married households, either the husband or the wife may have served as the survey respondent.

Although the measure of stated risk preference is based on the response of one household member, the measure of observed holdings of risky assets is based on data for all members of a household. Consequently, for single-headed households, there is a direct correspondence between the stated and the observed risk measures. However, for married households, there is the possibility that the household member responding to the survey question regarding risk tolerance is not the household member responsible for making financial investment decisions for the households. This biases the results against finding any gender differences in financial risk preferences.

The measure of observed risk tolerance is the ratio of risky financial assets to total financial asset owned by the household. Previous research by Friend and Blume (1975) and Siegal and Hoban (1991), for example, show that inferences about financial risk taking are sensitive to the definition of wealth employed. Because this analysis attempts to gauge how statements concerning financial risk preferences match up with the allocation of assets that would normally be considered by a financial planner, the measure of wealth chosen is limited to financial assets that are divisible and transactable. Consequently, excluded from this analysis is wealth held in the form of residential housing and other real estate, vehicles, business assets, consumer durables, human capital, and all liabilities. It is unclear the extent to which these excluded assets are owned for investment purposes in addition to consumption purposes. Moreover, human capital and business assets are certainly not infinitely divisible.

Financial assets are classified as either risky and risk free. This division is by nature arbitrary, but generally consistent with previous studies. Risk free assets are those with fixed nominal values, while all other assets are classified as risky. Risk free financial assets are defined to include dollar balances held in cash or on deposit in checking, savings, money market, or brokerage call accounts, as well as certificates of deposits, U.S. savings bonds, the cash value of life insurance polices, and IRA balances in certificates of deposits or other cash assets . Risky financial assets (including mixed-risk assets) include the value of balances in IRAs not held in certificates of deposit or other cash assets, bonds, stocks, mutual funds, trust assets, other financial assets (oil and gas leases, futures contracts, etc.), and balances in defined-contribution pensions and thrift plans.

Following other research, only those households in the survey with financial assets exceeding $\$ 2,500$ and headed by individuals aged 18 years or older are included in this analysis. This results in a final sample of 3,306 households. Table 1 provides summary statistics of the wealth variables for the households in the sample. In order to provide an estimate of how the measure of financial assets differs from broader measures of wealth used in other studies, the mean and median values of wealth, as defined by researchers at the Board of Governors of the Federal Reserve System, is presented in the table. In addition to financial assets, this measure of wealth includes the values of residential and investment real estate, business assets, and vehicles minus liabilities and debts incurred by the households. For the sample as a whole the mean value of financial assets represents approximately 44 percent of wealth and just 31 percent of the median value. The skewness of the distribution of wealth and financial assets is illustrated by the much larger mean than median values. The mean and median values of wealth and financial assets are larger for men on average than for women. For the sample as a whole and for both men and women separately, the mean value of risky assets exceeds the mean value of risk free assets; however, this finding is reversed for median values, i.e., the median household holds more risk free assets than risky assets. On average, men hold more risky and risk free assets than women. However, the median value of both risky and risk free assets are slightly higher for single women than for single men. 
Table 1. Means and Medians of Wealth Variables

\begin{tabular}{|l|r|r|r|r|r|r|r|}
\hline \multirow{2}{*}{ Variables } & \multicolumn{3}{|c|}{ Men } & \multicolumn{3}{|c|}{ Women } & All \\
\cline { 2 - 9 } & Married & \multicolumn{1}{c|}{ Single } & \multicolumn{1}{c|}{ Total } & \multicolumn{1}{c|}{ Married } & \multicolumn{1}{l|}{ Single } & \multicolumn{1}{l|}{ Total } & \\
\hline Wealth & & & & & & & \\
\hline Mean & 442,789 & 259,698 & 399,385 & 244,589 & 156,241 & 209,584 & 295,801 \\
\hline Median & 132,100 & 72,250 & 112,170 & 95,000 & 77,000 & 89,100 & 97,000 \\
\hline $\begin{array}{l}\text { Financial As- } \\
\text { sets }\end{array}$ & & & & & & & \\
\hline Mean & 195,605 & 126,875 & 179,311 & 97,526 & 78,434 & 89,962 & 130,549 \\
\hline Median & 43,750 & 20,000 & 36,500 & 26,390 & 22,600 & 25,000 & 30,000 \\
\hline $\begin{array}{l}\text { Risk Free As- } \\
\text { sets }\end{array}$ & & & & & & & \\
\hline Mean & 56,761 & 35,610 & 51,747 & 35,853 & 30,037 & 33,549 & 41,815 \\
\hline Median & 16,050 & 8,600 & 13,100 & 10,620 & 9,000 & 10,200 & 11,400 \\
\hline Risky Assets & & & & & & & \\
\hline Mean & 138,844 & 91,265 & 127,656 & 61,673 & 48,397 & 56,413 & 88,734 \\
\hline Median & 15,000 & 5,000 & 11,000 & 8,500 & 5,700 & 7,200 & 8,600 \\
\hline $\begin{array}{l}\text { Number of } \\
\text { Observations }\end{array}$ & 1,437 & 324 & 1,797 & 1,024 & 485 & 1,509 & 3,306 \\
\hline
\end{tabular}

Source: Author's tabulation of Survey of Consumer Finances 1995.

Although the Surveys of Consumer Finances are the best source of data on household wealth available for the U.S. and also include a measure of stated risk preference, these data do have some limitations. The most serious problem for this analysis is lack of information regarding who is the primary financial decision maker in married households. Consequently, the clearest comparisons of gender differences in risk preferences are for single households. However, the risk tolerance of single men and women may not be representative of married men and women. In addition, the SCF95 provides responses to only one question regarding risk tolerance. Financial planners typically ask numerous questions in order to assess an investor's tolerance of risk. Thus, any conclusions concerning the consistency of stated and observed risk tolerance must be tempered by these limitations.

\section{Empirical Evidence}

Table 2 reports the proportion of respondents selecting each category of risk preference classified by sex and marital status. More women than men indicated an unwillingness to take any financial risks: 42 percent of the women versus 29 percent of the men. At the opposite extreme, slightly more men indicated willingness to take substantial risks (5\%) than did women (3\%). The greater likelihood that women will express unwillingness to take risk is also found when the sample is categorized by marital status. In summary, the responses to the survey question regarding risk preferences indicate that women are more likely to indicate they are unwilling to take any financial risks, while men are more likely than women to indicate they are willing to take above average or substantial financial risks. 
Table 2. Stated Risk Preferences

\begin{tabular}{|c|c|c|c|c|c|c|c|}
\hline \multirow{2}{*}{$\begin{array}{l}\text { Risk Prefe- } \\
\text { rence }\end{array}$} & \multicolumn{3}{|c|}{ Men } & \multicolumn{3}{|c|}{ Women } & \multirow[t]{2}{*}{ All } \\
\hline & Married & Single & Total & Married & Single & Total & \\
\hline \multicolumn{8}{|c|}{ (Percentage of Respondents) } \\
\hline $\begin{array}{l}\text { Substantial } \\
\text { Risk }\end{array}$ & 3 & 8 & 5 & 3 & 3 & 3 & 4 \\
\hline $\begin{array}{l}\text { Above Aver- } \\
\text { age Risk }\end{array}$ & 20 & 20 & 20 & 14 & 11 & 13 & 16 \\
\hline Average Risk & 47 & 45 & 46 & 46 & 37 & 42 & 44 \\
\hline $\begin{array}{l}\text { Unwilling to } \\
\text { Take Risk }\end{array}$ & 30 & 27 & 29 & 37 & 49 & 42 & 36 \\
\hline Total & 100 & 100 & 100 & 100 & 100 & 100 & 100 \\
\hline $\begin{array}{l}\text { Number of } \\
\text { Observations }\end{array}$ & 1,473 & 324 & 1,797 & 1,024 & 485 & 1,509 & 3,306 \\
\hline
\end{tabular}

Source: Author's tabulation of Survey of Consumer Finances 1995.

Table 3 presents evidence of observed financial risk taking, i.e., the average ratio of risky assets to financial assets, for households classified by stated risk tolerance, gender and marital status. For every category of household, the proportion of risky assets held is higher for those indicating average risk preferences, compared to those expressing an unwillingness to take any financial risks. Likewise, those expressing a preference for above average risk hold proportionally more risky assets than those expressing a preference for only an average amount financial risk. However, in six out of seven comparisons, those expressing a willingness to take substantial financial risks hold a smaller proportion of risky assets than those indicating only an above average risk preference. Nevertheless, the stated risk preferences seem to provide at least an ordinal ranking of observed risk preferences on average.

Table 3. Risky Assets as a Percentage of Total Financial Assets by Stated Risk Preference

\begin{tabular}{|c|c|c|c|c|c|c|c|}
\hline \multirow{2}{*}{$\begin{array}{l}\text { Risk Prefe- } \\
\text { rence }\end{array}$} & \multicolumn{3}{|c|}{ Men } & \multicolumn{3}{|c|}{ Women } & \multirow{2}{*}{ All } \\
\hline & Married & Single & Total & Married & Single & Total & \\
\hline \multicolumn{8}{|c|}{ (Average Percentage) } \\
\hline $\begin{array}{l}\text { Substantial } \\
\text { Risk }\end{array}$ & 54 & 71 & 61 & 50 & 36 & 44 & 53 \\
\hline $\begin{array}{l}\text { Above Aver- } \\
\text { age Risk }\end{array}$ & 63 & 58 & 62 & 55 & 58 & 55 & 59 \\
\hline Average Risk & 49 & 42 & 48 & 51 & 47 & 50 & 49 \\
\hline $\begin{array}{l}\text { Unwilling to } \\
\text { Take Risk }\end{array}$ & 34 & 36 & 34 & 35 & 35 & 35 & 35 \\
\hline Total & 48 & 46 & 47 & 45 & 42 & 44 & 45 \\
\hline $\begin{array}{l}\text { Number of } \\
\text { Observations }\end{array}$ & 1,473 & 324 & 1,797 & 1,024 & 485 & 1,509 & 3,306 \\
\hline
\end{tabular}

Source: Author's tabulation of Survey of Consumer Finances 1995.

One of the most striking aspects of the data in Table 3 is the almost identical proportion of risky assets held on average by all categories of households indicating an unwillingness to take any financial risks. On average, approximately one-third of the assets held by these households is classified as risky, despite their stated unwillingness to take any financial risks. This proportion is the same for both men and women, single or married, in the sample. Table 4 presents evidence of this phenomenon from the opposite direction. Instead of looking at the proportion of risky assets held, this table presents the proportion of households holding only assets classified as risk free. Despite their stated unwillingness to take financial risks, only 42 percent of these households hold only risk free assets. Over half of these households hold risky assets, contradicting their stated unwillingness to take financial risks. This observation is also true for households classified by gender and marital status. The other very striking contrast pre- 
sented in this table is between single men and single women who indicate a willingness to take substantial financial risks. Of the single females professing to be willing to take the most financial risks, 42 percent are observed to hold only risk free assets, compared to just one percent of the single men who indicate a willingness to take substantial financial risks. To summarize, the statements of risk preference appear to be consistent with the observed allocation of financial assets between risky and risk free assets as an ordinal, but not as a quantitative, measure.

Table 4. Percentage of Households Holding Only Risk Free Assets By Stated Risk Preference

\begin{tabular}{|l|c|c|c|c|c|c|c|c|}
\hline \multirow{2}{*}{$\begin{array}{l}\text { Risk Prefe- } \\
\text { rence }\end{array}$} & \multicolumn{3}{|c|}{ Men } & \multicolumn{3}{c|}{ Women } & All \\
\cline { 2 - 9 } & Married & Single & Total & Married & Single & \multicolumn{2}{c|}{ Total } \\
\hline $\begin{array}{l}\text { Substantial } \\
\text { Risk }\end{array}$ & 18 & 1 & 11 & 11 & 42 & 24 & 17 \\
\hline $\begin{array}{l}\text { Above Aver- } \\
\text { age Risk }\end{array}$ & 8 & 13 & 9 & 12 & 19 & 15 & 11 \\
\hline Average Risk & 19 & 35 & 22 & 16 & 24 & 19 & 20 \\
\hline $\begin{array}{l}\text { Unwilling to } \\
\text { Take Risk }\end{array}$ & 39 & 44 & 40 & 42 & 43 & 43 & 42 \\
\hline \multicolumn{1}{|c|}{ Total } & 22 & 30 & 25 & 25 & 33 & 28 & 27 \\
\hline $\begin{array}{l}\text { Number of } \\
\text { Observations }\end{array}$ & 1,473 & 324 & 1,797 & 1,024 & 485 & 1,509 & 3,306 \\
\hline
\end{tabular}

Source: Author's tabulation of Survey of Consumer Finances 1995.

To evaluate gender differences in the relation between stated and observed risk preference in a more systematic manner, an analysis of variance model was estimated similar to the one employed by Schooley and Worden (1996). The proportion of risky assets was regressed against three dummy variables indicating whether the respondent expressed substantial, above average, or average risk preference. The omitted category is unwillingness to take any financial risks. Dummy variables indicating whether the respondent is female and whether the respondent is single are also included. The female dummy is interacted with the financial-risk variables and the variable indicating single marital status in order to determine whether the correspondence between stated and observed risk preferences differ by gender.

Table 5 presents the regression results. Each of the financial-risk variables is significantly different from zero at the one percent significance level. The estimated coefficients show that households indicating greater risk preferences hold significantly greater proportions of risky assets than households expressing an unwillingness to take any financial risks. Those indicating a preference for above average risk hold significantly more risky assets than those indicating only average risk preferences. However, there is no statistically significant difference in the proportion of risky assets held by households stating a preference for substantial financial risks, compared to households expressing an above average preference for risk. These results confirm the usefulness of the stated risk preference variable as an ordinal measure of a household's risk preference.

Although the female dummy is not statistically significant, two of the interaction terms of the female dummy with the indicators of risk preference are statistically significant. These estimated coefficients indicate that women expressing a preference for above average or substantial risk are estimated to hold a significantly smaller proportion of risky assets than males expressing these degrees of risk preference. Likewise, the statistical significance of the single dummy indicates that single respondents hold a smaller proportion of risky assets than comparable married respondents. 
Table 5. Regression Results: Dependent Variable - Proportion of Risky Assets

\begin{tabular}{|c|c|c|}
\hline $\begin{array}{l}\text { Independent } \\
\text { Variables }\end{array}$ & $\begin{array}{l}\text { Estimated } \\
\text { Coefficient }\end{array}$ & $\begin{array}{l}\text { Standard } \\
\text { Error }\end{array}$ \\
\hline Substantial Risk & $.273 * * *$ & .022 \\
\hline Above Average Risk & $.274 * * *$ & .012 \\
\hline Average Risk & $.131 * * *$ & .010 \\
\hline Female * Substantial Risk & $-.185 * * *$ & .032 \\
\hline Female * Above Average Risk & $-.069 * * *$ & .017 \\
\hline Female * Average Risk & .015 & .013 \\
\hline Female & .003 & .011 \\
\hline Single & $-.027 * * *$ & .001 \\
\hline Female * Single & .012 & .013 \\
\hline Constant & $.351 * * *$ & .008 \\
\hline Adjusted $\mathrm{R}^{2}$ & .059 & \\
\hline F Statistic & $115.24 * * *$ & \\
\hline Number of Observations & 3,306 & \\
\hline $\begin{array}{l}\text { Notes: } * * * \text { Indicates the coeff } \\
\text { at the } 1 \text { percent lev } \\
\text { and over in househ } \\
\text { than or equal to } \$ 2\end{array}$ & $\begin{array}{l}\text { ignificantly diffe } \\
\text { le is limited to } r \\
1995 \text { financial a }\end{array}$ & $\begin{array}{l}\text { ent from zer } \\
\text { spondents } 18 \\
\text { sets greater }\end{array}$ \\
\hline
\end{tabular}

Source: Author's computations based on Survey of Consumer Finances 1995.

\section{Summary and Conclusions}

This paper has examined gender differences in stated versus observed financial risk preferences. The responses of women versus men to questions regarding financial risk preferences were compared to the proportion of risky assets held in their portfolios using data from the SCF95. The data show that women are more likely to express an unwillingness to take financial risks. Stated financial risk preferences are found to be consistent with observed risk preferences at the ordinal, but not the quantitative, level. Contradicting their stated risk preferences, risky assets constitute, on average, one-third of the financial assets of households that indicate they are unwilling to take any financial risks.

Finding that households that express an unwillingness to tolerate any financial risk do in fact hold a substantial portfolio of risky assets combined with the greater tendency for women to express an unwillingness to tolerate financial risk has important policy implications. Financial planners and advisers frequently use a client's expressed willingness to take on risk as an important determinant in the asset allocation selected. Consistent gender differences in these responses, in addition to inconsistencies between the client's stated risk preferences and observed portfolio allocation, may lead advisers to make inappropriate recommendations. In particular, if women more consistently indicate that they are less willing to take financial risks, they may be advised to hold more conservative portfolios that in the long run may perpetuate the lower wealth levels of women compared to men.

The conclusions of this analysis are subject to a number of important caveats. As mentioned previously, the data do not allow us to determine who the financial decision-maker is in a married household, so that inferences pertaining to differences between married men or women are tenuous. In addition, while this analysis makes use of the response to one survey question to assign risk preferences, financial advisers may make use of more questions and one-on-one discussions to more adequately ascertain an individual's risk tolerance. 


\section{References}

1. Bajtelsmit, Vickie L., Alexandra Bernasek, and Nancy A. Jianakoplos. "Gender Differences in Defined Contribution Pension Decisions." Financial Services Review, 1999, pp. 1-10.

2. Bajtelsmit, Vickie L., and Jack A. VanDerhei. "Risk Aversion and Retirement Income Adequacy," in Positioning Pensions for the Twenty-first Century, edited by M.S. Gordon, O.S. Mitchell and M.M. Twinney. Philadelphia: University of Pennsylvania Press, 1997, pp. 45-66.

3. Fidelity Investments. Fidelity FundMatch Worksheet: Asset Allocation for Retirement. Boston, Mass. (no date).

4. Hinz, Richard P., David D. McCarthy, and John A. Turner. "Are Women Conservative Investors?: Gender Differences in Participant-Directed Pension Investments," in Positioning Pensions for the Twenty-first Century, edited by M.S. Gordon, O.S. Mitchell and M.M. Twinney. Philadelphia: University of Pennsylvania Press, 1997, pp. 91-103.

5. Ibbotson Associates._Stocks, Bonds, Bills, and Inflation: 1996 Yearbook.

6. Kennickell, Arthur, Martha Starr-McCluer, and Annika E. Sunden. "Family Finances in the U.S.: Recent Evidence from the Survey of Consumer Finances." Federal Reserve Bulletin, January 1997, pp. 1-24.

7. Jianakoplos, Nancy A. and Alexandra Bernasek. "Are Women More Risk Averse?" Economic Inquiry, October 1998, pp. 620-630.

8. Schooley, Diane K. and Debra Drecnik Worden. "Risk Aversion Measures: Comparing Attitudes and Asset Allocation." Financial Services Review, 5(2) 1996, pp. 87-99.

9. Sunden, Annika E. and Brian J. Surette. " Gender Differences in the Allocation of Assets in Retirement Savings Plans." American Economic Review, May 1998, pp. 207-211.

10. TIAA-CREF "Is It Time to Rebalance Your Retirement Portfolio?" The Participant, August 1998, pp.1114.

Notes 